\title{
Architectural effects on fossil preservation. The case of macaroni coralline algae
}

\author{
Juan C. BRAGA ${ }^{I^{*}}$ \& Fernando SOLA ${ }^{2}$
}

${ }^{1}$ Departamento de Estratigrafía y Paleontología, Universidad de Granada, Campus Fuentenueva, 18002, Granada, Spain

${ }^{2}$ Departamento de Biología y Geología, Universidad de Almería, 04120, Almería, Spain

* Corresponding author

Braga, J.C. \& Sola, F. 2017. Architectural effects on fossil preservation. The case of macaroni coralline algae. [Efectos de la arquitectura en la preservación de fósiles. El caso de las algas coralinas macarrón]. Spanish Journal of Palaeontology, 32 (1), 53-62.

\begin{abstract}
Coralline red algae with protuberances in their thalli are common and instructive examples of fabricational effects on fossil preservation. The body (thallus) of non-geniculate coralline algae is a coherent mass of cell filaments. All vegetative cells, except the epithallial ones at the tip of each filament are enclosed by a high-Mg calcite wall. Filament growth, and subsequent lateral expansion and thickening of the thallus occurs by repeated division of the cell immediately underneath the epithallial one. Many extant and extinct species of coralline algae have protuberances in their thalli. Protuberances appear both on the dorsal surface of algae that grow attached to a rigid substrate and in unattached specimens living on loose sediment. In either case, protuberances develop due to a higher growth rate of filaments in their centre. In each growth step, the cells formed at the protuberance apex are longer than coeval cells at the protuberance sides. The cell length decreases radially outwards from the protuberance tip. Consequently, central cells in protuberances are generally longer than lateral ones. Calcite walls of central, longer cells are thinner, less dense, and richer in $\mathrm{Mg}^{2+}$ than those of lateral cells. Accordingly, the former are more susceptible to dissolution during fossilization. As a result, dead and fossil coralline algae with protuberance centres partially or totally
\end{abstract}

\section{RESUMEN}

Las algas coralinas con protuberancias en el talo son ejemplos comunes e instructivos de los efectos de la construcción del esqueleto en su preservación como fósil. El cuerpo (talo) de las algas coralinas es una masa coherente de filamentos de células. Todas las células, excepto la epitaliales en el extremo del filamento, están enteramente rodeadas por paredes de calcita magnesiana. El crecimiento de los filamentos, y con ello la expansión lateral y el incremento de grosor del talo, se produce por la división repetida de la célula situada inmediatamente debajo de la epitalial. Muchas especies actuales y extinguidas de algas coralinas presentan protuberancias, que aparecen en la superficie dorsal de las algas fijas a un sustrato o en las formas libres sobre sedimento suelto. En ambos casos, las protuberancias se desarrollan por una mayor tasa de crecimiento de las células en sus filamentos centrales. En cada etapa de crecimiento, las células formadas en el ápice son más largas que sus coetáneas en los laterales de la protuberancia. La longitud de las células decrece radialmente desde el ápice de la protuberancia y, consecuentemente, las células centrales en general son más largas que las laterales. Las paredes calcíticas de las células centrales son más delgadas, menos densas, y más ricas en $\mathrm{Mg}^{2+}$ que las de las células laterales. Por ello, las paredes de las 
dissolved are relatively common. In these cases, protuberances occur as structures with an empty or vuggy central part and well-preserved sides. This macaroni-like preservation of corallines is particularly common in Cenozoic maerl deposits, formed mainly by concentrations of unattached branching coralline thalli.

Keywords: Coralline red algae, taphonomy, microarchitecture, $\mathrm{Mg}$ calcite.

\section{INTRODUCTION}

Variations in microarchitecture imply differential susceptibility to taphonomic processes of dissimilar parts within a single skeleton. Microarchitectural differences involve different responses of shells or shell portions to physical and chemical, pre- and postburial, taphonomic processes (Kidwell \& Bosence, 1991). The surface:volume ratio, generally expressed as shell thickness, microstructure of layers, distribution of organic matrix, and intraskeletal porosity influence the resistance to dissolution of skeletal minerals (Walter, 1984; Canfield \& Raiswell, 1991). In addition, the Mg content affects calcite solubility (Bischoff et al., 1985) and controls differential loss of calcitic skeletons (Canfield \& Raiswell, 1991). Microarchitectural traits involve a fabricational aspect due to the physical constraints that determine organism development and, in particular, the construction of skeletons (Seilacher, 1973; Vögel, 1991).

Fabricational constraints are patent in the internal microarchitecture of protuberances of the calcareous coralline algae. Protuberances arise from the thallus (algal body) surface due to differential growth of central cells within.

In this study, we compare living corallines with a bizarre case of fossil coralline algae, in which the branches are preserved as tubes (here called macaroni corallines) (Fig. 1) to understand the taphonomic processes leading to such a peculiar preservation. We aim to show that 1) the growth of coralline algal protuberances involves differences from the centre to the sides in cell size, and cell-wall thickness and composition; and 2) these fabricational microarchitectural features imply differential fossilization of portions within the protuberances, leading in extreme cases to macaroni preservation.

Coralline algae. The largest living group of calcareous algae, coralline algae are common fossils in marine-shelf deposits ever since their appearance in the Early Cretaceous células centrales son más susceptibles a la disolución durante la fosilización. Como resultado, son relativamente comunes las algas coralinas fósiles con los centros de las protuberancias parcial o totalmente disueltos, con una estructura cavernosa o completamente huecos, mientras que los laterales están bien preservados. Esta preservación en forma de macarrón es particularmente frecuente en los depósitos de maerl del Cenozoico, formados por concentraciones de algas coralinas ramosas.

Palabras clave: Algas rojas coralinas, tafonomía, microarquitectura, calcita magnesiana.
(Aguirre et al., 2000; Chatalov et al., 2015). They live mainly in marine waters from subpolar seas to the Equator, extending from the intertidal zone to about 100-120 m depth (Adey \& Macintyre, 1973; Bosence, 1991; McCoy \& Kamenos, 2015), although they have been exceptionally recorded at $270 \mathrm{~m}$ (Littler et al., 1985). Modern corallines are major building organisms in bioconstructions formed along wide ranges of depths and latitudes (Adey, 1986, 1998; Bosence, 1991). They also grow attached to soft and hard substrates or unattached (rhodoliths) on sediment bottoms in areas of low terrigenous influx. Recently, encrusting coralline algae have also been found living in fresh water, on a river bed in a karstic area far from the sea (Žuljević et al., 2016). Fossil coralline algae are common components in sedimentary rocks, especially in Cenozoic

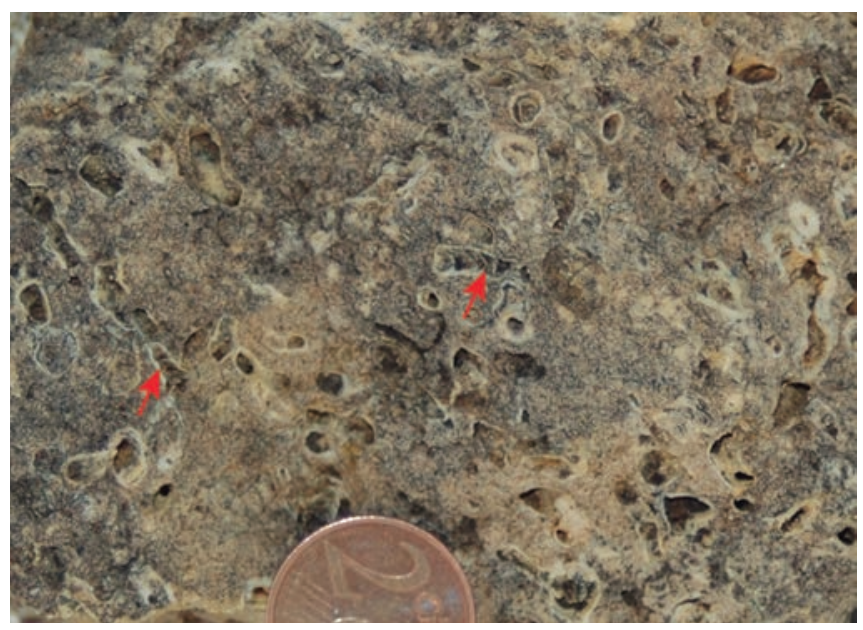

Figure 1. Macaroni coralline algae. In most cases only the lateral portions of branches are preserved, giving a tubular aspect to fossil corallines. In some specimens the smaller-sized cells of growth bands are also preserved (red arrows). Late Tortonian (late Miocene), La Chanata, Sierra de Gádor, Almería, SE Spain. Coin diameter: $18 \mathrm{~mm}$. 
shallow-water carbonates (Halfar \& Mutti, 2005; Aguirre et al., 2017), where they occur mainly as components of reef structures or as bioclasts in detrital deposits. As photoautotrophs, coralline algae are sensitive to light gradients, being dependent mainly on depth and turbidity, and susceptible to other environmental factors such as grazing pressure, temperature, turbulence, salinity, and alkalinity (Adey \& Macintyre, 1973; Adey, 1986; Steneck, 1986; McCoy \& Kamenos, 2015). The habitat preferences of living assemblages and morphological traits related to environmental conditions have been used to interpret the sedimentary environments of the rocks in which fossil corallines appear (Adey \& McIntyre, 1973; Adey, 1979, 1986; Bosence, 1983, 1991; Braga \& Aguirre, 2001, 2004; Webster et al., 2009).

The body (thallus) of coralline algae is pseudoparenchymatous, i.e. formed by a coherent mass of cell filaments. Lateral expansion on the substrate and increases in thallus thickness are achieved by filament growth, which takes place by repeated division in two of the cells immediately underneath the one at the filament tip (epithallial cell). In non-geniculate corallines (also called crustose corallines), cells in vegetative filaments are surrounded by calcite walls, except epithallial cells, which are not entirely covered at the thallus dorsal surface.
The walls are made by high-Mg calcite, creating a rigid skeleton, in which only the reproductive structures and injury sites undergoing reparation are not mineralized (McCoy \& Kamenos, 2015). In geniculate (or articulated) corallines, thallus segments of fully calcified cells are separated by segments of non-calcified ones (genicula), which provide a certain flexibility to the algal body. The calcite composition of the algal skeleton varies by species, cell type, and the age of the coralline (Borowitzka, 1982). Cell dimensions range typically from 5 to 20 microns in width and 5 to 40 microns in length but vary greatly even within a single thallus (Figs 2-4).

The rigid skeleton of thick non-geniculate coralline algae (those with a thallus thicker than 100 microns) has a high preservation potential and these kinds of corallines have an excellent and diverse fossil record (Aguirre et al., 2000). By contrast, the skeletons of thin non-geniculate corallines (thalli thinner than 100 microns) can easily be destroyed by biogenic and physical processes and, when preserved, are usually micritized. Calcified segments of geniculate corallines disarticulate and disperse as sandgrade grains after post-mortem decay of non-calcified parts and, consequently, geniculate forms have a poor fossil record.

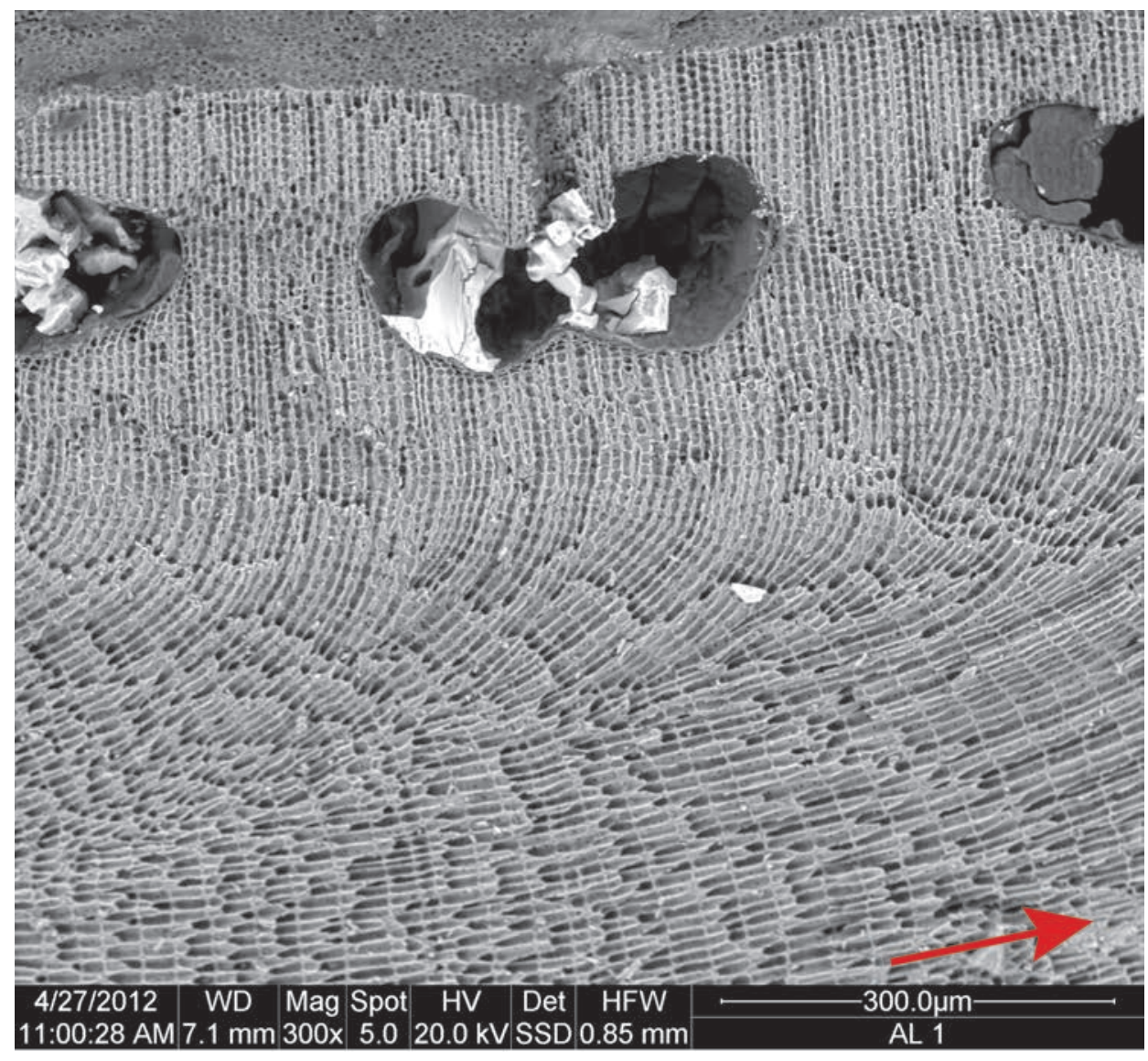

Figure 2. Half longitudinal section of a living Lithophyllum sp. branch. The branch grew to the right of the image (red arrow). Note the decrease in cell size and cell-wall thickening from the branch centre (bottom) to the branch side (top) in each phase of cell formation delimited by transversal cell walls. The flask-shaped structures at the top are sporangial conceptacles. Cells of adjacent filaments are connected by secondary pits (small holes at cell walls). Alborán Island shelf. Sample AL.1 


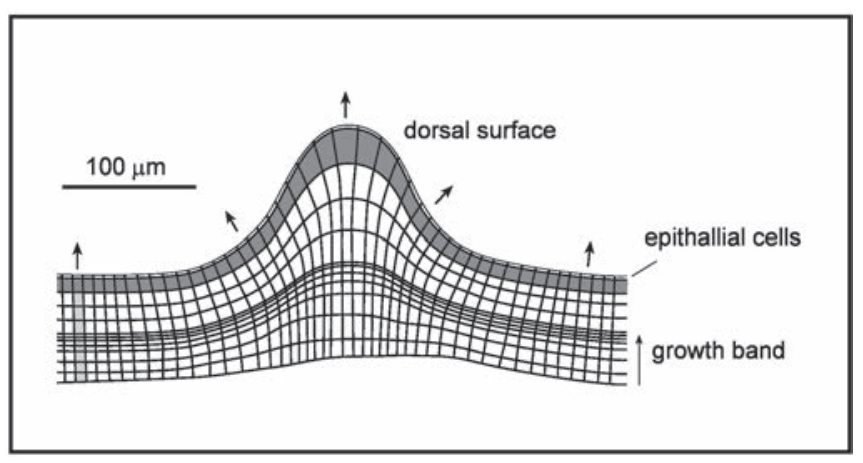

Figure 3. Simplified scheme of a protuberance development on the dorsal surface of a crustose coralline thallus. Note the decrease in cell size from protuberance centre to sides. Cell size does not significantly change in nonprotuberant portions of thallus. Arrows indicate growth direction of filaments. Grey-coloured cells formed in a single phase of thallus growth.

The thalli of attached, thick, non-geniculate corallines show distinct ventral (the one attached to the substrate) and dorsal surfaces. The dorsal surface can be smooth or develop protuberances, from small warts to long (several $\mathrm{cm}$ ) branches. Protuberances of diverse size and shape can also grow on the outer surface of unattached corallines (rhodoliths). Protuberances develop by filament division and differential growth of cells. In each growth step, the cells formed at the protuberance tip are longer than coeval cells at the protuberance sides. The cell length decreases radially outwards from the protuberance tip (Figs 2-4). Consequently, cells in central filaments in protuberances are generally longer than cells in lateral filaments. The

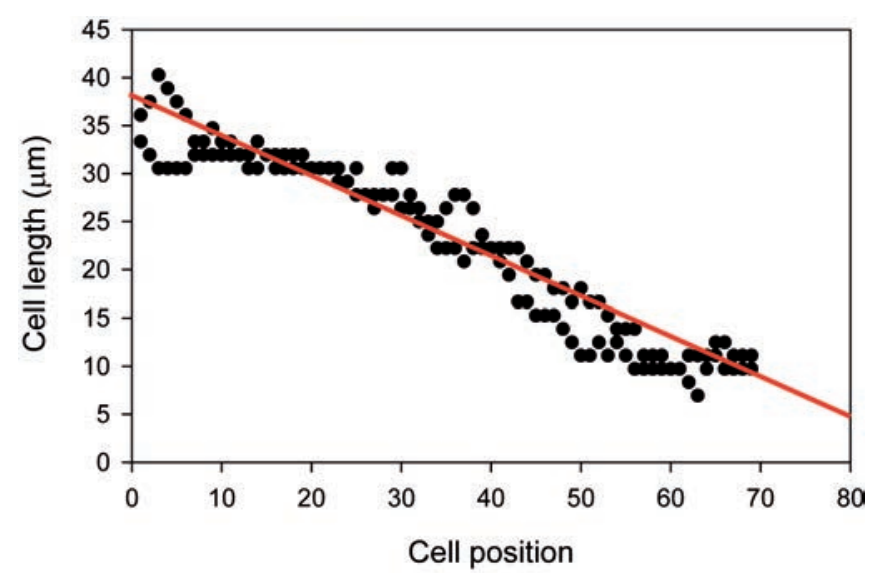

Figure 4. Simple linear regression of cell length and cell position from protuberance centre (position 1) to side (position 69 ) in two growth stages in the Lithophyllum sp. specimen in Fig. 2. Correlation coefficient: 0.96, $p_{0}$ $<0.01$ differential growth of cells in central filaments takes place even if the thallus shows growth bands due to changing environmental conditions.

Cell shape and size as well as chemical composition and density of calcite walls change within a coralline thallus (Kamenos et al., 2017). These changes are most commonly expressed as annual or subannual growth bands (Figs 3, 5). Bands can reflect annual changes in light and temperature, lunar growth cycles related to tides, burial by sediment and larger scale climate patterns such as El Niño (Foster, 2001; Kamenos et al., 2017). Cells with lower calcite density (thinner walls and smaller cell-wall:cell-volume ratio) form at warmer temperatures. Higher-density bands of smaller cells with relatively thicker walls are formed in periods of lower temperatures or of a combination of lower temperature and lesser light availability (Kamenos, 2010; Burdett et al., 2011; Kamenos et al., 2017).

The $\mathrm{Mg}$ content in cell-wall calcite increases with faster growth, implying a direct relationship between $\mathrm{Mg}$ content and temperature (Chave \& Wheeler, 1965; Milliman et al., 1971). According to Kamenos et al. (2008, 2009), the replacement of $\mathrm{Ca}^{2+}$ by $\mathrm{Mg}^{2+}$ in the calcite crystal may be directly controlled by temperature and not by growth rate.

\section{METHODS}

Branches of two living rhodoliths from the shelf of Alborán Island in the Alborán sea and of one from the eastern Almería shelf (western Mediterranean) were cut into thin polished sections to examine the internal structure and composition of vegetative filaments. Cell shape and size distribution, and skeletal density (thickness of cell walls) within the branches were examined under a FEI Quanta-400 ESEM (CIC Universidad de Granada, Spain). $\mathrm{The} \mathrm{Mg}, \mathrm{Sr}$, and $\mathrm{Ca}$ content in calcite cell walls within two branches was mapped by EDS in an electron-probe microanalyser (CAMECA SX100, CIC Universidad de Granada).

Samples of fossil coralline algae from upper Tortonian limestones from La Chanata in Sierra de Gádor (SE Spain) (Sola et al., 2013, 2017), showing the characteristic macaroni preservation, were cut in ultrathin sections, examined under an optical microscope (Olympus CX31), and photographed with an Axiocam MRc camera.

All samples are deposited in the algal collection of the Departamento de Estratigrafía y Paleontología, Universidad de Granada. 


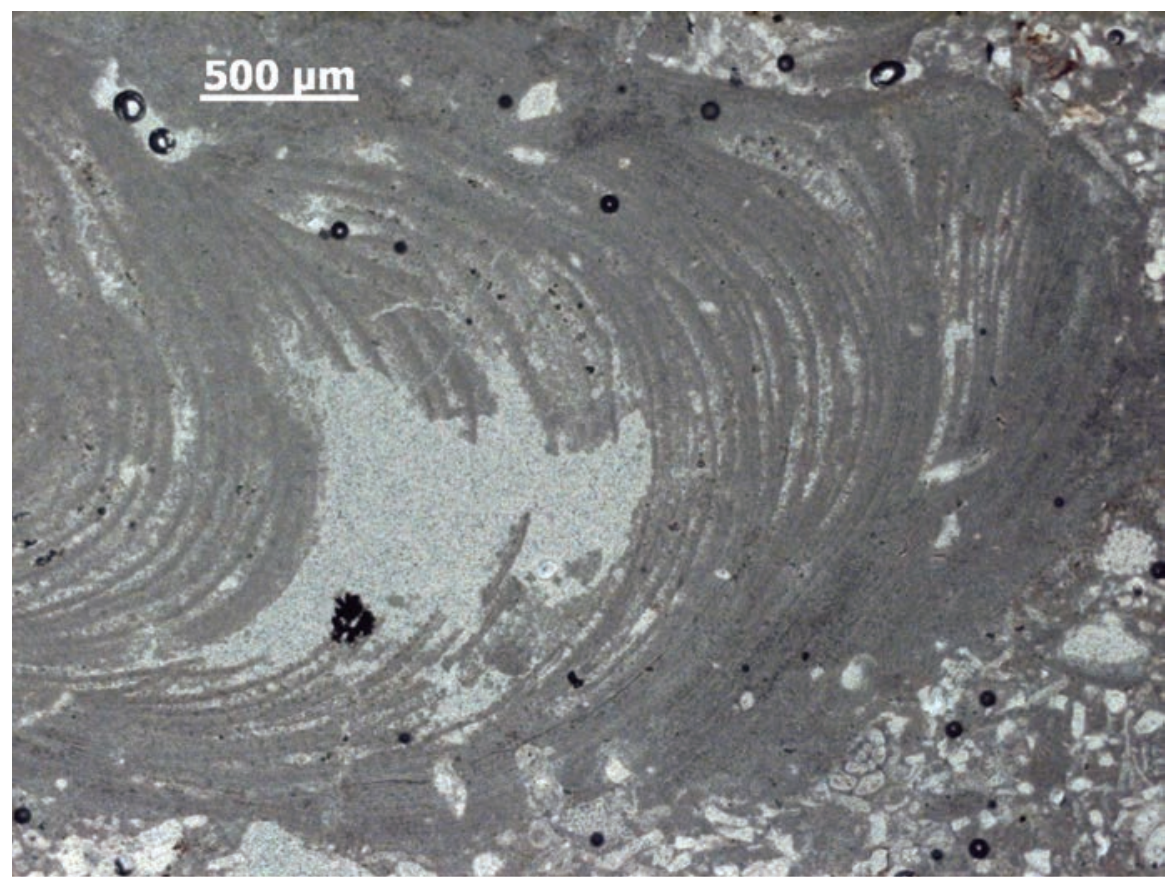

Figure 5. Longitudinal thin section of a fossil melobesioid branch. Note the selective dissolution of branch centre and lighter zones of growth bands (coupled lighter and darker zones). Late Tortonian (late Miocene), La Chanata, Sierra de Gádor, Almería, SE Spain.

\section{RESULTS}

\subsection{Differential preservation in fossil rhodolith branches}

The selected examples of upper Tortonian corallines have a peculiar preservation as the rhodolith branches are tubular (macaroni-like) (Fig. 1) instead of consisting of a solid mass of contiguous calcified cell filaments. The field aspect of branches suggests that only the external lateral portion of them is preserved, whereas the branch centre is empty. A marked differential preservation of cells and cell filaments can also be discerned under the microscope. Cells in lighter, less dense zones in growth bands and cells in central filaments of the protuberances are preferentially dissolved and have partly or totally disappeared (Figs 5-6). In extreme cases, all cells in central filaments, including the denser ones of growth bands, are dissolved away (Fig. 7). This differential dissolution is trans-taxonomic, affecting both branches of Lithophyllum (subfamily Lithophylloideae, family Corallinaceae, order Corallinales) (Fig. 7) and branches of melobesioids (subfamily Melobesioideae, family Hapalidiaceae, order Hapalidiales) (Figs 5-6).

\subsection{Changes in cell dimension and composition in living rhodolith branches}

In the branches examined of living rhodoliths belonging to Lithophyllum sp. and the melobesioid Lithothamnion sp.,

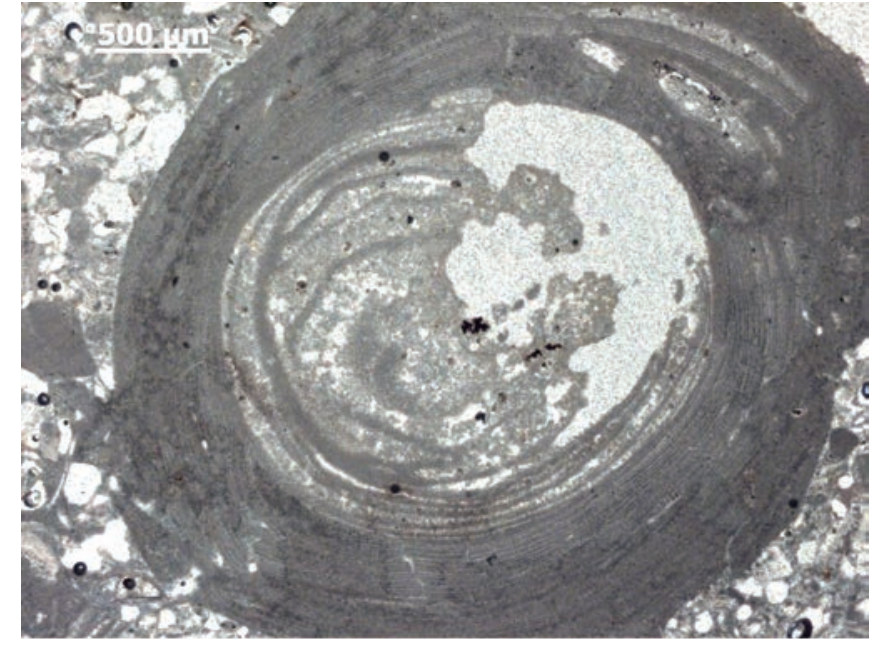

Figure 6. Transversal thin section of a fossil melobesioid branch. Note the selective dissolution of branch centre and the higher resilience of darker (denser) zones of growth bands. Late Tortonian (late Miocene), La Chanata, Sierra de Gádor, Almería, SE Spain.

filaments show a fan- or fountain-like arrangement due to the radial decrease in cell length from the central filaments to the lateral ones (Figs 2-4). In each cell generation (growth step), cells in central filaments possess thinner walls than cells at the branch sides (Fig. 2). This pattern is superimposed over the changes in skeletal density and average cell dimensions due to growth bands, which probably reflect annual (or subannual) changes in water temperature and light availability (McCoy \& Kamenos, 2015). 


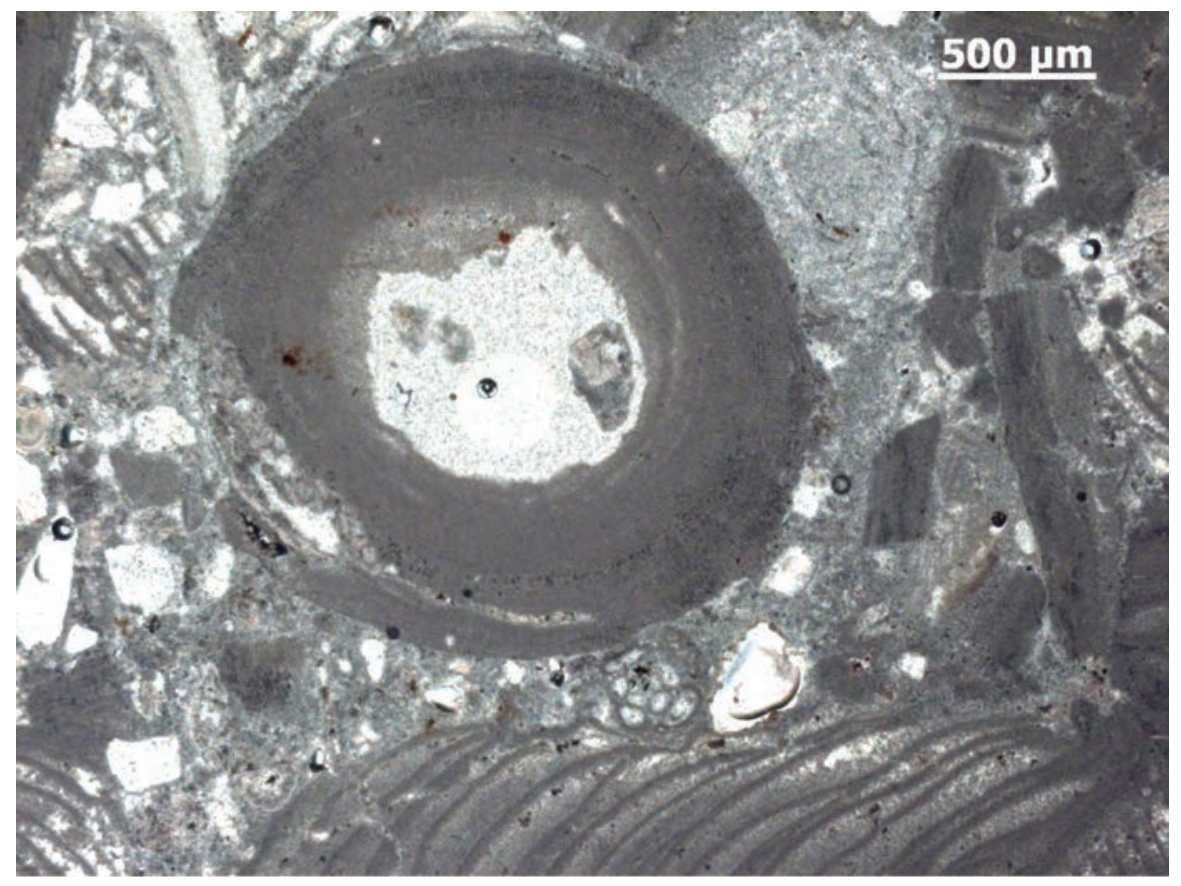

Figure 7. Transversal thin section of a fossil Lithophyllum sp. branch. Note the advanced dissolution of branch centre. Late Tortonian (late Miocene), La Chanata, Sierra de Gádor, Almería, SE Spain.

The element mapping reveals that $\mathrm{Mg}^{2+}$ content is higher in central filaments than in lateral ones in each step of branch development (Fig. 8). The $\mathrm{Mg}^{2+}$ content is also higher in lighter (less dense) intervals of growth bands, those formed in warmer periods, probably with higher illumination (Halfar et al., 2000, 2008; Kamenos et al., 2008, 2012; Kamenos, 2010; Burdett et al., 2011; Caragnano et al., 2014) (Fig. 8). In any interval of a growth band, however, $\mathrm{Mg}^{2+}$ content is higher in central cells than in lateral ones.

\section{DISCUSSION}

When the patterns of cell size and $\mathrm{Mg}^{2+}$ content in living corallines are taken into account, the differential preservation patterns in fossil corallines can be explained by preferential dissolution of zones within the thallus with relatively longer and lighter (thinner calcite walls) cells, and higher $\mathrm{Mg}^{2+}$ content in calcite crystals of the skeleton. There is a clear correspondence between density of the skeleton (cell-wall thickness) and the $\mathrm{Mg}^{2+}$ content in the living corallines analysed (Figs 2, 8). This correspondence is superimposed over growth bands determined by changes in environmental conditions, probably caused by annual variation in temperature and illumination (McCoy \& Kamenos, 2015; Kamenos et al., 2017). Whatever the environmental conditions, in each growth stage the central cells of the branch are longer and possess thinner walls than the coeval lateral ones. At any growth stage the central cells have a higher content of $\mathrm{Mg}^{2+}$ in the calcite

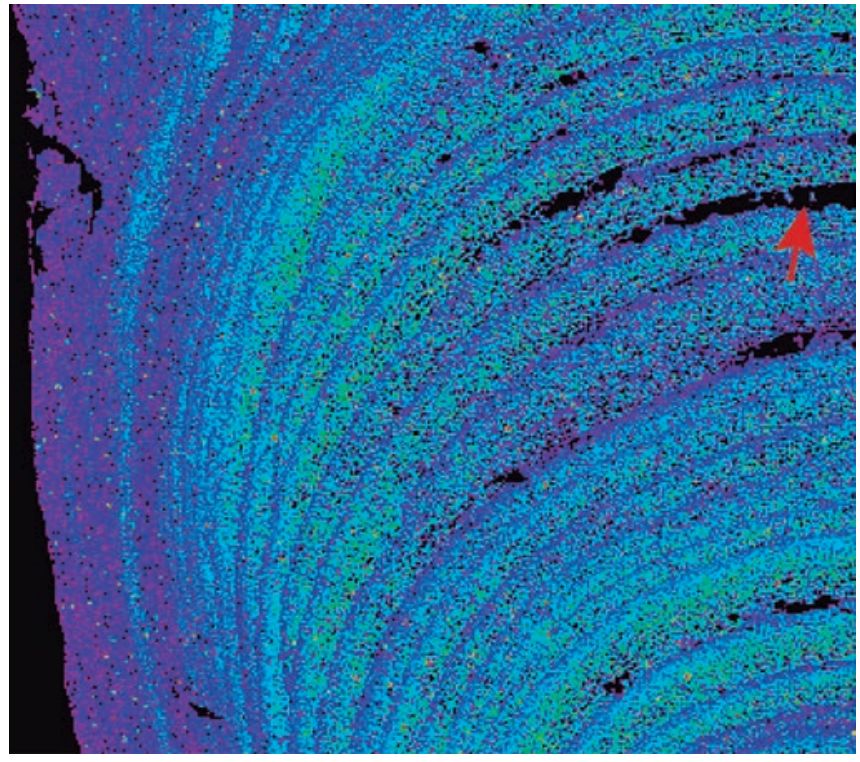

Figure 8. Element map of $\mathrm{Mg}$ in a branch of living Lithothamnion $\mathrm{sp}$. Note the marked higher concentration of $\mathrm{Mg}$ (green) in the branch centre and lighter zones of growth bands. Lighter intervals of growth zones are partially dissolved (red arrow). Alborán Island shelf. Sample M69/1 379.1.

lattice, probably due to their faster growth, as suggested in pioneer works on $\mathrm{Mg}$ in calcite of coralline algae (Moberly, 1968; Kolesar, 1978). Any increment in the $\mathrm{Mg}^{2+}$ content in calcite increases mineral solubility (Bischoff et al., 1985; Paquette \& Reeder, 1990) affecting preservation potential of calcite skeletons. In addition, thinner cell walls have more volume exposed to chemical dissolution 
than do thicker ones. This surface/volume effect has been suggested as a factor conditioning differential preservation of shells (Flessa \& Brown, 1983). Consequently, lighter cell walls as well as higher $\mathrm{Mg}^{2+}$ content make the longest cells in each growth stage more vulnerable to dissolution. The branch centres are more prone to disappear under the influence of marine and fresh water. One of the living specimens examined from the Alboran Island shows incipient loss of the centres of the lighter portion of the oldest growth bands (Fig. 8), suggesting that dissolution of the weakest parts of the skeleton (highest $\mathrm{Mg}^{2+}$ content and thinnest cell walls) can start before the death of the alga.

Macaroni corallines in the upper Tortonian limestones of Sierra de Gádor (Fig. 1) are an extreme case of differential preservation of microstructures within a single skeleton due to differences in microarchitecture. The fabricational effects on skeletal robustness and composition at a sub-millimetre scale have in this example drastic taphonomic implications leading to the preservation of only the external lateral portions of branches. Differential partial to total dissolution of protuberance centres is common in the fossil record of corallines, even if it has hardly been mentioned in the literature (Fig. 9). As shown by the upper Tortonian examples, this kind of preservation occurs in coralline algae of diverse taxonomic affinities.

Local factors such as permeability of the hosting rock or chemical composition of meteoric waters can affect the degree of dissolution of the coralline branches. Two other factors might have a broader significance in the preservation patterns of coralline algae.

The difference in length between central and lateral cells depends on the length/width relationship of the protuberance. Although branch development in unattached coralline algae can be controlled by water turbulence (Bosence, 1976), it depends primarily on the growth form of the taxon. Intraspecific morphological variability can be very high and growth habit is usually not a diagnostic character (Woelkerling, 1988; Pardo et al., 2014), but species and species groups tend to share a common geometry of protuberances. Hence, the length:width ratio of protuberances is taxon related and the subsequent differential preservation of branch microstructures could depend on the temporal and spatial distribution of coralline taxa.

On the other hand, solubility of high- $\mathrm{Mg}$ calcites decreases with temperature (Bertram et al., 1991), implying that general dissolution of corallines and differential dissolution of the lighter parts of their skeletons will be more accentuated in colder waters. This means that macaroni corallines and a higher degree of differential dissolution of protuberance centres in fossil corallines will be more common in higher latitudes and in relatively colder periods in the geological history of a region. This latter is true of the time of deposition of the Azagador Member

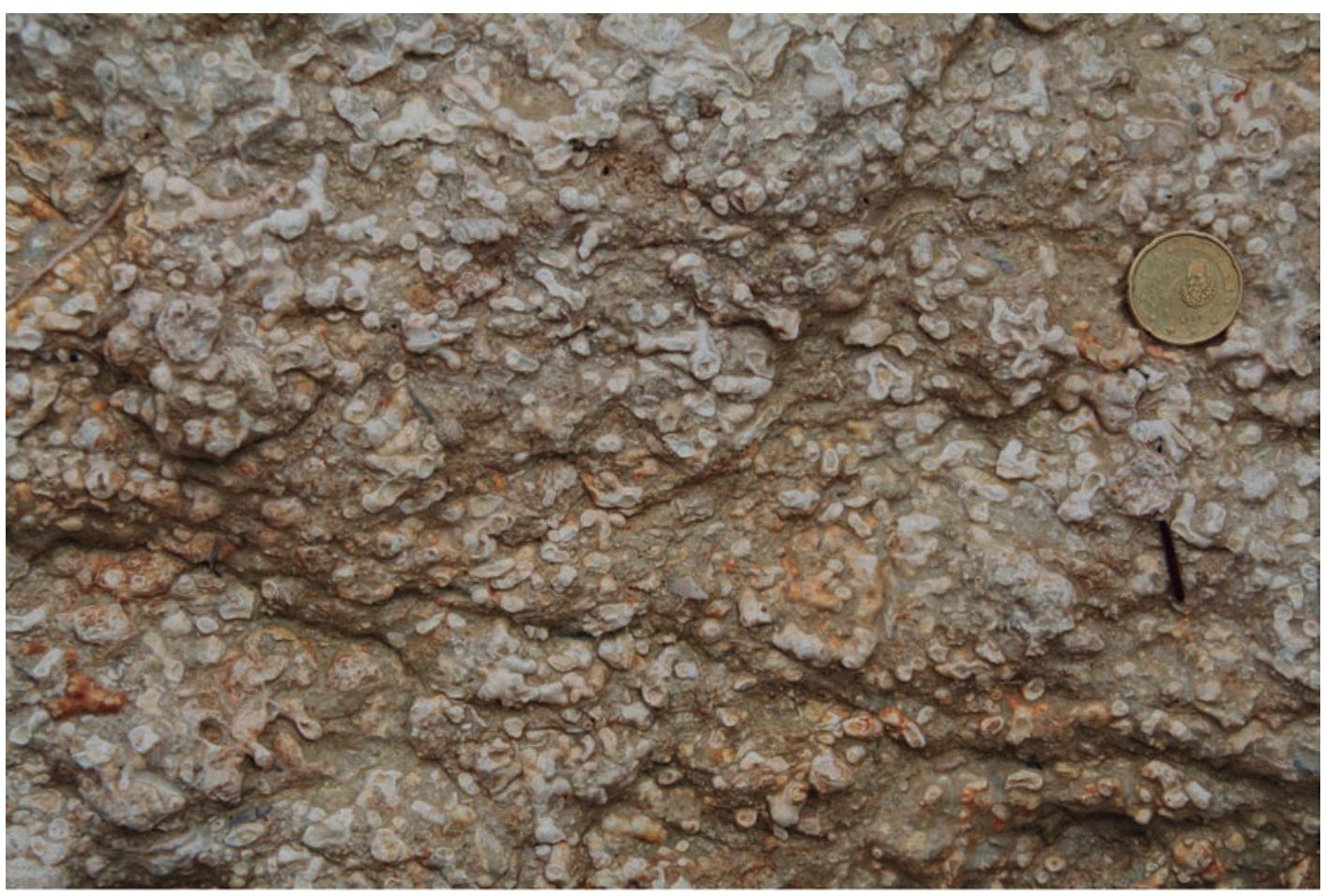

Figure 9. Branching rhodoliths in the Azagador Member (late Tortonian) in the Molino del Río Aguas section (Puga-Bernabéu et al., 2007). Branches with preferentially dissolved centre are common in this coralline algal concentration. Coin diameter: $22 \mathrm{~mm}$. 
in the Neogene basins of SE Spain (Figs 1,9) to which the upper Tortonian limestones of Sierra de Gádor can be attributed (Sola et al., 2013, 2017). This was an interval of sea-surface temperatures in the western Mediterranean lower than in previous and subsequent periods characterized by coral reef growth (Martin \& Braga, 1994; SánchezAlmazo et al., 2001; Martín et al., 2010).

Water temperature generally cools with depth and, consequently, patterns of greater differential dissolution within coralline skeletons with increasing palaeodepth might be expected. However, no detailed observations on such patterns have been attempted to date. Palaeoenvironmentally dependent, as well as taxon- and latitude-related patterns of differential preservation in corallines have yet to be explored, but the abundance of these calcareous algae and the relative simplicity of the approaches to study their taphonomical features make this group an excellent model to study taphonomic bias along environmental and geographical gradients.

\section{CONCLUSIONS}

In living coralline algae cells in the centre of thallus protuberances are longer and lighter (possess thinner walls), and have a higher $\mathrm{Mg}^{2+}$ content than cells at the periphery of the same protuberances.

This microarchitectural disparity is due to differential cell growth needed to develop a protuberance: cells in the centre have to grow faster than peripheral ones at any growth stage. Such a growth pattern is superimposed to changes in length and density affecting all cells in the thallus due to annual variations in temperature and light intensity (growth bands).

These microarchitectural features imply different preservation potential. Lighter walls of cells richer in $\mathrm{Mg}^{2+}$ in the centre are more soluble and are generally worse preserved than cells at the outer parts of protuberances. Macaroni corallines are an extreme case of this kind of differential preservation in which cells in protuberance centres are completely dissolved.

\section{ACKNOWLEDGEMENTS}

This work was funded by "Ministerio de Economía y Competitividad", Spain, project CGL2013-47236-P and the "Fondo Europeo de Desarrollo Regional (FEDER)". The authors are indebted to Davide Bassi, an anonymous reviewer, and JSP editor Julio Aguirre by their helpful comments. We are also grateful to David Nesbitt who edited the English text.

\section{REFERENCES}

Adey, W.H. 1979. Crustose coralline algae as microenvironmental indicators in the Tertiary. In: Historical Biogeography, Plate Tectonics and the Changing Environment (eds Gray, J. \& Boucot, A.J.). Oregon State University Press, Corvallis, 459-464.

Adey, W.H. 1986. Coralline algae as indicators of sea-level. In: Sea-Level Research: a Manual for the Collection and Evaluation of Data (ed. van de Plassche, O.). Free University of Amsterdam, Netherlands, 229-280.

Adey, W.H. 1998. Coral reefs: algal structured and mediated ecosystems in shallow, turbulent, and alkaline waters. Journal of Phycology, 34, 393-40; doi: 10.1046/j.15298817.1998.340393.x.

Adey, W.H. \& Macintyre, I.G. 1973. Crustose coralline algae: a re-evaluation in the geological sciences. Geological Society of America Bulletin, 84, 883-904; doi: 10.1130/0016-7606.

Aguirre, J., Riding, R. \& Braga, J.C. 2000. Diversity of coralline red algae: origination and extinction patterns from the Early Cretaceous to the Pleistocene. Paleobiology, 26, 651-667; doi: 10.1666/0094-8373(2000)026<0651:DOC $\mathrm{RAO}>2.0 . \mathrm{CO} ; 2$.

Aguirre, J., Braga, J.C. \& Bassi, D. 2017. Rhodoliths and Rhodolith Beds in the Rock Record. In: Rhodolith/Maërl Beds: A Global Perspective (eds Riosmena-Rodríguez, R., Nelson, W. \& Aguirre, J.). Coastal Research Library, Springer, 15, 105-138; doi: 10.1007/978-3-319-293115-8_5.

Bertram, M.A., Mackenzie, F.T., Bishop, F.C. \& Bischoff, W.D. 1991. Influence of temperature on the stability of magnesian calcite. American Mineralogist, 76, 1889-1896.

Bischoff, W.D., Sharma, S.K. \& Mackenzie, F.T. 1985. Carbonate ion disorder in synthetic and biogenic magnesian calcites: A Rarnan spectral study. American Mineralogist, 70, 581-589.

Borowitzka, M.A. 1982. Mechanisms in algal calcification. In: Progress in Phycological Research (eds Round, F.E. \& Chapman, D.J.). Biomedical Press, Amsterdam, 1, 137-77.

Bosence, D.W.J. 1976. Ecological studies on two unattached coralline algae from western Ireland. Palaeontology, 19, 365-395.

Bosence, D.W.J. 1983. The occurrence and ecology of recent rhodoliths. In: Coated Grains (ed. Peryt, T.M.). Springer, Berlin, 225-242.

Bosence, D.W.J. 1991. Coralline algae: mineralization, taxonomy, and palaeoecology. In: Calcareous Algae and Stromatolites (ed. Riding, R.). Springer, Berlin, 98-113.

Braga, J.C. \& Aguirre, J. 2001. Coralline algal assemblages in upper Neogene reef and temperate carbonates in Southern Spain. Palaeogeography, Palaeoclimatology, Palaeoecology, 175, 27-41; doi: 10.1016/S00310182(01)00384-4.

Braga, J.C. \& Aguirre, J. 2004. Coralline algae indicate Pleistocene evolution from deep open platform to outer barrier reef environments in the northern Great Barrier Reef margins. Coral Reefs, 23, 547-558; doi: 10.1007/ s00338-004-0414-x. 
Burdett, H.L., Kamenos, N.A. \& Law, A. 2011. Using coralline algae to understand historic marine cloud cover. Palaeogeography, Palaeoclimatology, Palaeoecology, 302, 65-70; doi: 10.1016/j.palaeo.2010.07.027.

Canfield, D.E. \& Raiswell, R. 1991. Carbonate precipitation and dissolution. Its relevance to fossil preservation. In: Taphonomy: Releasing the Data Locked in the Fossil Record (eds Allison, P.A. \& Briggs, D.E.G.). Topics in Geobiology, Plenum Press, New York, 9, 411-453.

Caragnano, A., Basso, D., Jacob, D.E., Storz, D., Rodondi, G., Benzoni, F. \& Detrieux, E. 2014. The coralline red alga Lithophyllum kotschyanum f. affine as proxy of climate variability in the Yemen coast, Gulf of Aden (NW Indian Ocean). Geochimica et Cosmochimica Acta, 124, 1-17; doi: 10.1016/ j.gca.2013.09.021.

Chatalov, A., Bonev, N. \& Ivanova, D. 2015. Depositional characteristics and constraints on the mid-Valanginian demise of a carbonate platform in the intra-Tethyan domain, Circum-Rhodope Belt, northern Greece. Cretaceous Research, 55, 84-115; doi: 10.1016/j. cretres.2015.02.001.

Chave, K.E. \& Wheeler, B.D., Jr. 1965. Mineralogic changes during growth in the red alga, Clathromorphum compactum. Science, 147, 621; doi: 10.1126/science.147.3658.621.

Flessa, K.W. \& Brown, T.J. 1983. Selective solution of macroinvertebrate calcareous hard parts: a laboratory study. Lethaia, 6, 193-205; doi: 10.1111/j.1502-3931.1983. tb00654.x.

Foster, M.S. 2001. Rhodoliths: between rocks and soft places. Journal of Phycology, 87, 659-667; doi: 10.1046/j.15298817.2001.00195.x.

Halfar, J. \& Mutti, M. 2005. Global dominance of coralline red-algal facies: a response to Miocene oceanographic events. Geology, 33, 481-484; doi: 10.1130/G21462.1.

Halfar, J., Zack, T., Kronz, A. \& Zachos, J.C. 2000. Growth and high-resolution paleoenvironmental signals of rhodoliths (coralline red algae): a new biogenic archive. Journal of Geophysical Research, 105, 22107-22116; doi: 10.1029/1999JC000128.

Halfar, J., Steneck, R.S., Joachimski, M., Kronz, A. \& Wanamaker, A.D., Jr. 2008. Coralline red algae as high resolution climate recorders. Geology, 36, 463-466; doi: 10.1130/G24635A.1.

Kamenos, N.A. 2010. North Atlantic summers have warmed more than winters since 1353, and the response of marine zooplankton. Proceedings of the National Academy of Sciences of the United States of America, 107, 2244222447; doi: 10.1073/pnas.1006141107.

Kamenos, N.A., Cusack, M. \& Moore, P.G. 2008. Red coralline algae are global paleothermometers with biweekly resolution. Geochimica et Cosmochimica Acta, 72, 771-779; doi: 10.1016/j.gca.2007.11.019.

Kamenos, N.A., Cusack, M., Huthwelker, T., Lagarde, P. \& Scheibling, R.E. 2009. Mg-lattice associations in red coralline algae. Geochimica et Cosmochimica Acta, 73, 1901-1907; doi: 10.1016/j.gca.2009.01.010.

Kamenos, N.A., Hoey, T.B., Nienow, P., Fallick, A. \& Claverie, T. 2012. Reconstructing Greenland ice sheet runoff using coralline algae. Geology, 40, 1095-1098; doi: 10.1130/G33405.1.

Kamenos, N.A., Burdett, H.L. \& Darrenougue, N. 2017. Coaralline algae as recorders of past climatic and environmental conditions. In: Rhodolith/Maërl Beds: A Global Perspective (eds Riosmena-Rodríguez, R., Nelson, W. \& Aguirre, J.). Coastal Research Library, Springer, 15, 105-138; doi: 10.1007/978-3-319-293115-8 2.

Kidwell, S.M. \& Bosence, D.W.J. 1991. Taphonomy and time-averaging of marine shelly faunas. In: Taphonomy: Releasing the Data Locked in the Fossil Record (eds Allison, P.A. \& Briggs, D.E.G.). Topics in Geobiology, Plenum Press, New York, 9, 115-209.

Kolesar, P.T. 1978. Magnesium in calcite from a coralline alga. Journal of Sedimentary Petrology, 48, 815-820; doi: 10.1306/212F7572-2B24-11D7-8648000102C1865D.

Littler, M.M., Littler, D.S., Blair, S.M. \& Norris, J.N. 1985. Deepest known plant life discovered on an uncharted seamount. Science, 227, 57-59; doi: 10.1126/ science.227.4682.57.

Martín, J.M. \& Braga, J.C. 1994. Messinian events in the Sorbas Basin in southeastern Spain and their implications in the recent history of the Mediterranean. Sedimentary Geology, 90, 257-268; doi: 10.1016/0037-0738(94)90042-6.

Martín, J.M., Braga, J.C., Sánchez-Almazo, I.M. \& Aguirre, J. 2010. Temperate and tropical carbonate-sedimentation episodes in the Neogene Betic basins (southern Spain) linked to climatic oscillations and changes in AtlanticMediterranean connections: constraints from isotopic data. In: Carbonate Systems During the Oligocene-Miocene Climatic Transition (eds Mutti, M., Piller, W.E. \& Betzler, C.). IAS Spec. Publ., 42, 49-69.

McCoy, S.J. \& Kamenos, N.A. 2015. Coralline algae (Rhodophyta) in a changing world: integrating ecological, physiological, and geochemical responses to global change. Journal of Phycology, 51, 6-24; doi: 10.1111/ jpy. 12262

Milliman, J.D., Gastner, M. \& Müller, J. 1971. Utilization of magnesium in coralline algae. Geological Society of America Bulletin, 82, 573-80; doi: 10.1130/0016-7606(1971)82[573:UOMICA]2.0.CO;2.

Moberly, R.J. 1968. Composition of magnesian calcites of algal and pelecypods by electron microprobe analysis. Sedimentology, 11, 61-82; doi: 10.1111/j.1365-3091.1968. tb00841.x.

Paquette, F. \& Reeder, R.J. 1990. Single-crystal X-ray structure refinements of two biogenic magnesian calcite crystals. American Mineralogist, 75, 1151-1158.

Pardo, C., Lopez, L., Peña, V., Hernández-Kantún, J., Le Gall, L., Barbara, I. \& Barreiro, R. 2014. A multilocus species delimitation reveals a striking number of species of coralline algae forming maerl in the OSPAR Maritime Area. PLoS ONE, 9, e104073; doi: 10.1371/journal. pone.0104073.

Puga-Bernabéu, Á., Martín, J.M. \& Braga, J.C. 2007. Tsunami-related deposits in temperate carbonate ramps, Sorbas Basin, southern Spain. Sedimentary Geology, 199, 107-127; doi: 10.1016/j.sedgeo.2007.01.020. 
Sánchez-Almazo, I.M., Spiro, B., Braga, J.C. \& Martín, J.M. 2001. Constraints of stable isotope signatures on the depositional palaeoenvironments of upper Miocene reef and temperate carbonates in the Sorbas Basin, SE Spain. Palaeogeography, Palaeoclimatology, Palaeoecology, 175, 153-172; doi: 10.1016/S0031-0182(01)00391-1.

Seilacher, A.1973. Fabricational noise in adaptive morphology. Systematic Zoology, 22, 451-465; doi: 10.2307/2412952.

Sola, F., Braga, J.C. \& Aguirre, J. 2013. Hooked and tubular coralline algae indicate seagrass beds associated to Mediterranean Messinian reefs (Poniente Basin, Almería, SE Spain). Palaeogeography, Palaeoclimatology, Palaeoecology, 374, 218-229; doi: 10.1016/j. palaeo.2013.01.020.

Sola, F., Puga-Bernabéu, Á., Aguirre, J. \& Braga, J.C. 2017. Heterozoan carbonate deposition on a steep basement escarpment (Late Miocene, Almería, SE Spain). Sedimentology; doi: 10.1111/sed.12343.

Steneck, R.S. 1986. The ecology of coralline algal crusts: convergent patterns and adaptive strategies. Annual Review of Ecology and Systematics, 17, 273-303.
Vögel, K. 1991. Concepts of constructional morphology. In: Constructional Morphology and Evolution (eds SchmidtKittler, N. \& Vögel, K.) Springer, Berlin, 55-68.

Walter, L.M. 1984. Magnesian calcite solubilities: A reevaluation. Geochimica et Cosmochimica Acta, 48, 1059-1069; doi: 10.1016/0016-7037(84)90196-0.

Webster, J.M., Braga, J.C., Clague, D.A., Gallup, C., Hein, J.R., Potts, D.C., Renema, W., Riding, R., RikerColeman, K., Silver, E. \& Wallace, L.M. 2009. Coral reef evolution on rapidly subsiding margins. Global and Planetary Change, 66, 129-148; doi: 10.1016/j. gloplacha.2008.07.010.

Woelkerling, W.J. 1988. The Coralline Red Algae: An Analysis of the Genera and Subfamilies of Nongeniculate Corallinaceae. Oxford University Press, Oxford.

Žuljević, A., Kaleb, S., Peña, V., Despalatović, M., Cvitković, I., De Clerck, O., Le Gall, L., Falace, A., Vita, F., Braga, J.C. \& Antolić, B. 2016. First freshwater coralline alga and the role of local features in a major biome transition. Scientific Reports, 6, 19642; doi: 10.1038/srep19642. 